48. O'Hara Y, Takasaki Y 1979 Relationship between plasma glutamate levels and hypothalamic lesions in rodents. Toxicol Lett 4:499-505

49. Daabees TT, Finkelstein MW, Stegink LD, Applebaum AE 1985 Correlation of glutamate plus aspartate dose, plasma amino acid concentration and neuronal necrosis in infant mice. Food Chem Toxicol (in press)

50. Takasaki Y 1978 Studies on brain lesions after administration of monosodium L-glutamate to mice. II. Absence of brain damage following administration of monosodium l-glutamate in the diet. Toxicology 9:307-318

51. Anantharaman K 1979 In utero and dietary administration of monosodium L-glutamate to mice: reproductive performance and development in a multigeneration study. In: Filer LJ Jr, Garattini S, Kare MR, Reynolds WA, Wurtman RJ, (eds) Glutamic Acid: Advances in Biochemistry and Physiology. Raven Press, New York, pp 231-253

\title{
ANNOUNCEMENTS
}

\section{First I.U.I.S. Conference on Clinical Immunology}

A 2-day conference on clinical immunology will be held in conjunction with the VIth International Congress of Immunology, in Toronto, Canada, from July 5-6, 1986. These dates immediately precede the VIth International Congress. The conference will encompass plenary sessions, minisymposia, and a poster session. Among the major topics: receptor-anti-receptor mediated diseases; new trends in the management of disorders of autoimmunity, immunodeficiency, allergy, immunodiagnostic techniques, and transplantation; and a session concerned with human diseases caused by lymphotropic retroviruses.

Registration and abstract forms may be obtained from: Mr. K. Charbonneau, National Research Council of Canada, Ottawa, Ontario K1A OR6, Canada.

\section{0th International Convocation on Immunology Buffalo, NY, July 14-17, 1986 \\ Vaccines: New Concepts and Developments}

The Ernest Witebsky Center for Immunology will present this symposium in its regular biennial series at the Hyatt Regency Buffalo Hotel following the VIth International Congress of Immunology in Toronto, Canada, which is only 100 miles distant. Closed plenary sessions will focus on the topics: Conceptual Basis of Antigens; Antigen Identification and Purification; Host Response; Production of Vaccines by Recombinant DNA Techniques: Idiotype Vaccines; and Human and Veterinary Vaccines. Open poster sessions for free contributions on the theme will be offered.

For further information contact: Dr. James F, Mohn, Director, The Ernest Witebsky Center for Immunology, 210 Sherman Hall, State University of New York at Buffalo, Buffalo, NY 14214 (716-831-2848). 